\title{
Analisis Faktor Determinan Kinerja Bidan dalam Pelaksanaan Asuhan Persalinan Normal di Kabupaten Merangin Tahun 2019
}

\author{
Dian Mayasari ${ }^{1}$, Hardisman $^{2}$, Desmiwarti ${ }^{3}$ \\ ${ }^{1}$ Prodi S2 kebidanan Fakultas kedokteran Universitas Andalas \\ ${ }^{2}$ Fakultas Kesehatan Masyarakat Universitas Andalas padang \\ ${ }^{3}$ Fakultas kedokteran Universitas Andalas Padang \\ Correspondence e-mail: dianmayasari_mr@yahoo.co.id
}

\begin{abstract}
Abstrak. Berdasarkan profil kesehatan Provinsi Jambi (2015) cakupan APN oleh tenaga kesehatan di Kabupaten Merangin kesehatan belum mencapai target. Hal tersebut menunjukkan kinerja Bidan di Desa secara makro belum optimal. Beberapa faktor yang berhubungan dengan kinerja seorang tenaga kesehatan dalam memberikan pelayanan kesehatan yaitu: variabel individu, variabel psikologis dan variabel organisasi. Tujuan penelitian ini untuk menganalisis faktor determinan kinerja bidan dalam pelaksanaan APN di Kabupaten Merangin tahun 2018. Desain penelitian ini yaitu observasional analitik dengan pendekatan cross sectional. Penelitian ini telah dilakukan di wilayah Kerja Dinas Kesehatan Kabupaten Merangin Februari - Agustus 2019, dengan populasi seluruh bidan di Kabupaten Merangin sebanyak 608 orang. Jumlah sampel sebanyak 83 orang yang diambil dengan teknik simple random sampling. Analisis data bivariat menggunakan uji chi square dan analisis multivariat menggunakan regresi logistk berganda. Hasil penelitian yaitu ada hubungan tingkat pengetahuan ( $p=0,000 ; \mathrm{OR}: 10,879 ; 95 \% \mathrm{Cl} ; 3,832-30,8850)$ dan pengalaman ( $p=0,000 ;$ OR:7,292;95\% $\mathrm{Cl}=2,683,19,818)$ dengan kinerja bidan dalam pelaksanaan APN, tidak ada hubungan persepsi tentang penghargaan $(p=0,991)$, sikap $(p=0,351)$, persepsi tentang peralatan $(p=0,261)$ pelatihan $(p=0,660)$ dengan kinerja bidan dalam pelaksanaan APN di Kabupaten Merangin serta faktor yang paling berpengaruh dengan kinerja bidan dalam pelaksanaan APN di Kabupaten Merangin yaitu tingkat pengetahuan bidan ( $p=0,000 ; 0 R ; 24,607)$. Disarankan kepada kepada bidan lebih meng update informasi tentang APN guna meningkatkan pengetahuan bidan dalam APN.
\end{abstract}

Kata kunci : APN; Faktor determinan; Kinerja bidan

Abstract. Based on health profile of Jambi Province (2015) NLC coverage by health worker in Merangin district health has not reached the target. It shows the macro performance of midwives in the village is not optimal. Some factors related to the performance of a healthcare worker in providing health services are: Individual variables, psychological variables and organizational variables. The purpose of this research is to analyze the factors determinant of the performance of midwives in the implementation of in Merangin year 2018. This type of research is analytic observation with cross sectional approach, this research has been conducted in the work area of Merangin District Health Office February until August 2019, with the population of all midwives in the district Merangin as much as 608 people. The number of samples was 83 people taken with simple random sampling technique. Bivariate analysis using Chi Square test and multivariate analysis using binary logistic regression. The results of the study there was a level of knowledge relationship ( $p=0,000 ;$ OR:10,879; $95 \% \mathrm{Cl} ; 3,832-30,8850)$ and the experience of midwives ( $p=0,000$; OR:10,879; $95 \% C l ; 3,832-30,8850)$ with the performance of midwives in the implementation of the NLC, no perceptual relationship about the award $(P=0,991)$, attitude $(P=0,351)$, perception of the NLC equipment $(p=0,261)$, Midwives Training $(0,660)$ with the performance of midwives in the implementation of NLC in Merangin Regency and the most influential factor with the performance of midwives in the implementation of NLC in Merangin District namely the level of knowledge of. Advised to the midwives more update information about the NLC to improve the knowledge of midwives in the NLC.

Keyword: Determinant Factor; Midwife Performance; Normal Labour Care (NLC)

\section{PENDAHULUAN}

Angka Kematian Ibu (AKI) dan Angka Kematian Bayi (AKB) merupakan salah satu indikator utama derajat kesehatan suatu negara. AKI menggambarkan jumlah wanita yang meninggal dari suatu penyebab kematian akibat proses kelahiran, persalinan, dan pasca persalinan/ 100.000 kelahiran hidup (Dinas Kesehatan Provinsi Jambi, 2016). Saat ini status kesehatan ibu dan anak di Indonesia masih jauh dari yang diharapkan, ditandai dengan masih tingginya AKI.

Penyebab kematian ibu yaitu terjadi karena komplikasi kebidanan yang tidak ditangani dengan baik dan tepat waktu, namun saat terjadinya komplikasi dalam kehamilan persalinan dan masa nifas tidak dapat diprediksi. Oleh karena itu diperlukan penanganan yang tepat oleh tenaga kesehatan dalam asuhan kehamilan, persalinan dan nifas (Alchadi, 2019).

Penerapan Standar APN merupakan upaya yang terintegrasi dan lengkap, namun menggunakan intervensi seminimal mungkin sehingga prinsip keamanan dan kualitas layanan dapat terjaga pada tingkat yang seoptimal mungkin berdasarkan standar yang ada dan pendekatan seperti ini berarti bahwa dalam APN harus ada alasan yang kuat dan bukti manfaat apabila akan melakukan intervensi terhadap jalannya proses persalinan yang fisiologis/alamiah (Watimena, 2008). APN memunculkan dua sudut pandang yang berbeda. Pertama, persalinan harus dikenali sebagai proses fisiologis normal yang sebagian besar perempuan mengalaminya tanpa komplikasi. Kedua, komplikasi persalinan yang muncul secara cepat dan tiba-tiba harus diantisipasi. Petugas kesehatan harus bisa membuat setiap ibu dan bayi selamat jika sewaktu-waktu terjadi komplikasi (Cunningham et al., 2013).

Berdasarkan profil kesehatan Provinsi Jambi (2015) cakupan APN oleh tenaga kesehatan belum mencapai target. Artinya kinerja bidan di desa secara makro belum optimal. Beberapa faktor yang mempengaruhi kinerja seorang tenaga kesehatan dalam memberikan pelayanan kesehatan yaitu: variabel individu, variabel psikologis dan variabel organisasi. 
Tujuan penelitian ini yaitu untuk menganalisis faktor determinan kinerja bidan dalam pelaksanaan APN di Kabupaten Merangin tahun 2018.

\section{METODE PENELITIAN}

Desain penelitian ini yaitu observasional analitik dengan pendekatan cross sectional, Penelitian ini telah dilakukan di wilayah Kerja Dinas Kesehatan Kabupaten Merangin Desember 2018-Februari 2019, dengan populasi seluruh bidan di Kabupaten Merangin sebanyak 608 orang. Jumlah sampel sebanyak 83 orang yang diambil dengan teknik simple random sampling.

Pengumpulan data dilakukan melalui data primer dan data sekunder. Data primer pada penelitian ini dilakukan dengan menggunakan lembar observasi checklist APN 60 langkah dan kuesioner. Kuesioner yang digunakan adalah kuesioner yang telah dimodifikasi dan di adopsi dari penelitian dan dilakukan uji validitas dan reliabilitas sebelumnya sedangkan lembar observasi checklist APN 60 langkah telah dijadikan standar baku oleh JNPK-KR (Jaringan nasional Pelatihan Klinik Kesehatan Reproduksi) sebagai instrumen penilaian kinerja peserta untuk setiap keterampilan/kegiatan APN. Data Sekunder pada penelitian ini dilakukan dengan menelusuri dan menelaah laporan-laporan atau dokumen-dokumen yang berhubungan dengan masalah yang diteliti yang didapat dari Dinas Kesehatan Kabupaten Merangin. Analisis data dilakukan secara bivariat menggunakan uji chi square dan analisis multivariat menggunakan regresi logistik berganda.

\section{HASIL DAN PEMBAHASAN}

Tabel 1. Hubungan Pengetahuan Dengan Kinerja Bidan Dalam APN Di Kabupaten Merangin Tahun 2019

\begin{tabular}{|c|c|c|c|c|c|c|c|c|}
\hline \multirow[t]{3}{*}{ Pengetahuan } & \multicolumn{4}{|c|}{ Kinerja Bidan } & \multicolumn{2}{|c|}{ Total } & \multirow[t]{3}{*}{$p$ value } & \multirow[t]{3}{*}{ OR $(95 \% \mathrm{Cl})$} \\
\hline & \multicolumn{2}{|c|}{ Tidak Baik } & \multicolumn{2}{|c|}{ Baik } & & & & \\
\hline & $f$ & $\%$ & $\mathrm{~F}$ & $\%$ & $\mathrm{~F}$ & $\%$ & & \\
\hline Rendah & 33 & 71,7 & 13 & 28,3 & 46 & 100 & 0,000 & $10,879(3,832-0,885)$ \\
\hline Tinggi & 7 & 18,9 & 30 & 81,1 & 37 & 100 & & \\
\hline Total & 40 & 48,2 & 43 & 51,8 & 83 & 100 & & \\
\hline
\end{tabular}

Hasil penelitian ini diketahui bahwa kinerja bidan yang baik lebih banyak pada bidan dengan tingkat pengetahuan tinggi (81,1\%). Hasil Uji statistik menunjukkan ada hubungan pengetahuan bidan dengan kinerja bidan dalam pelaksanaan APN $(p=0,000)$ dengan OR $(10,879 ; 95 \% \mathrm{Cl}=3,832-30,885)$.

Hasil penelitian ini sejalan dengan penelitian Longgupa (2011) yang menemukan bahwa terdapat hubungan yang signifikan antara pengetahuan bidan dengan kinerja bidan dalam asuhan persalinan normal. Pengetahuan merupakan faktor individu yang dapat membentuk tindakan seseorang, pengetahuan didapatkan melalui pengalaman pribadi yang terjadi berulang kali termasuk di dalamnya adalah proses pengajaran.

Pengetahuan dapat membentuk tindakan seseorang. Perilaku seseorang dapat berubah jika perubahan tersebut didasari oleh pengetahuan, kesadaran, dan sikap positif (Notoatmojo, 2007). Tingginya pengetahuan responden tentang asuhan persalinan mendorong bidan untuk melakukan APN dengan baik dan benar. Pada penelitian ini ditemukan $81,1 \%$ responden dengan kinerja baik berasal dari bidan dengan pengetahuan yang tinggi. Artinya, semakin tinggi pengetahuan bidan maka kecendrungan untuk memiliki kinerja yang baik akan semakin tinggi.

Tabel 2. Hubungan Sikap Dengan Kinerja Bidan Dalam APN Di Kabupaten Merangin Tahun 2019

\begin{tabular}{|c|c|c|c|c|c|c|c|c|}
\hline \multirow{3}{*}{ Sikap } & \multicolumn{4}{|c|}{ Kinerja Bidan } & \multicolumn{2}{|l|}{ Total } & \multirow{3}{*}{$p$ value } & \multirow{3}{*}{ OR $(95 \%$ Cl $)$} \\
\hline & \multicolumn{2}{|c|}{ Tidak baik } & \multicolumn{2}{|c|}{ Baik } & & & & \\
\hline & $f$ & $\%$ & $f$ & $\%$ & $f$ & $\%$ & & \\
\hline Negatif & 16 & 55,2 & 13 & 44,8 & 29 & 100 & 0,351 & $1,538(0,621-3,813)$ \\
\hline Positif & 24 & 44,4 & 30 & 55,6 & 54 & 100 & & \\
\hline Total & 40 & 48,2 & 43 & 51,8 & 83 & 100 & & \\
\hline
\end{tabular}

Hasil penelitian menunjukkan bahwa kinerja bidan yang baik lebih banyak pada bidan yang memiliki sikap positif. Hasil uji statistik menunjukkan tidak ada hubungan sikap bidan dengan kinerja bidan dalam pelaksanaan APN.

Penelitian ini sejalan dengan hasil penelitian Longgupa (2011) yang menyatakan faktor sikap tidak berpengaruh terhadap kinerja bidan $(p>0,05)$. Sikap merupakan suatu pernyataan evaluatif seseorang terhadap obyek tertentu, orang tertentu atau peristiwa tertentu, sikap juga merupakan cerminan perasaan seseorang terhadap sesuatu (Siagian, 2012).

Hasil analisis distribusi frekuensi diketahui bahwa kinerja responden yang baik cenderung lebih tinggi pada responden dengan sikap positif, namun dapat dilihat juga jumlah responden dengan sikap yang positif dalam penelitian juga banyak yang memiliki kinerja yang tidak baik $(44,4 \%)$.

Hasil uji statistik menunjukkan bahwa penelitian ini tidak sejalan dengan teori yang ada dapat dimaklumi karena kinerja tidak hanya ditentukan oleh faktor sikap saja melainkan dipengaruhi multi faktor yang saling berkaitan. Selanjutnya, menurut Azwar (2010) Objek sikap adalah segala sesuatu (benda, orang, hal) yang bisa dinilai oleh manusia. Dimensi pertimbangan dalam sikap berupa skala positif-negatif, seperti dari baik ke buruk, dari bagus ke jelek, dari haram ke halal, dari syah ke tidak syah, dari enak ke tidak enak. Dengan demikian, sikap adalah menempatkan suatu objek ke dalam salah satu skala pertimbangan. Sikap menentukan perilaku seseorang dalam hubungannya dengan stimulus manusia atau kejadian-kejadian tertentu. Sikap merupakan suatu keadaan yang memungkinkan timbulnya suatu perbuatan atau tingkah 
laku (Djunawan, 2015). Menurut asumsi peneliti, sikap tidak selalu memiliki hubungan dengan dengan kinerja karena kinerja seseorang tidak hanya dipengaruhi oleh faktor tunggal saja tetapi multifaktor yang saling terkait membentuk suatu kinerja.

Selain itu, sikap manusia tidak terbentuk sejak manusia dilahirkan. Sikap manusia terbentuk melalui proses sosial yang terjadi selama hidupnya, dimana individu mendapatkan informasi dan pengalaman. Proses tersebut dapat berlangsung di dalam lingkungan keluarga, sekolah maupun masyarakat. Saat terjadi proses sosial terjadi hubungan timbal balik antara individu dan sekitarnya Adanya interaksi dan hubungan tersebut kemudian membentuk pola sikap individu dengan sekitarnya. Azwar (2010) menguraikan faktor pembentuk sikap yaitu: pengalaman yang kuat, pengaruh orang lain yang dianggap penting, pengaruh kebudayaan, media masa, lembaga pendidikan dan lembaga agama, pengaruh faktor emosional.

Tabel 3. Hubungan Persepsi Tentang Penghargaan Dengan Kinerja Bidan Dalam APN Di Kabupaten Merangin Tahun 2019

\begin{tabular}{|c|c|c|c|c|c|c|c|c|}
\hline \multirow[t]{3}{*}{ Persepsi Penghargaan } & \multicolumn{4}{|c|}{ Kinerja Bidan } & \multicolumn{2}{|c|}{ Total } & \multirow[t]{3}{*}{$p$ value } & \multirow[t]{3}{*}{ OR $(95 \% \mathrm{Cl})$} \\
\hline & \multicolumn{2}{|c|}{ Tidak baik } & \multicolumn{2}{|c|}{ Baik } & & & & \\
\hline & $f$ & $\%$ & f & $\%$ & & $\%$ & & \\
\hline Kurang & 14 & 48,3 & 15 & 51,7 & 29 & 100 & 0,991 & $1,005(0,407-2,480)$ \\
\hline Baik & 26 & 48,1 & 28 & 51,9 & 54 & 100 & & \\
\hline Total & 40 & 48,2 & 43 & 51,8 & 83 & 100 & & \\
\hline
\end{tabular}

Hasil penelitian menunjukkan bahwa kinerja bidan yang baik lebih banyak pada bidan yang memiliki persepsi tentang penghargaan positif. Hasil uji statistik menunjukkan tidak ada hubungan persepsi tentang penghargaan dengan kinerja bidan dalam pelaksanaan APN.

Hasil penelitian ini tidak sejalan dengan penelitian yang dilakukan oleh Sutrisno (2017) bahwa ada hubungan antara insentif dengan kinerja Perawat di RSUD kota Semarang. Secara statistik hubungan insentif dengan kinerja perawat bermakna ( $p$ value: 0,001). Begitu juga dengan penelitian Aswad (2016) menyebutkan bahwa kompensasi berpengaruh signifikan terhadap kinerja perawat di Rumah Sakit UIT Makassar.

Menurut hasil analisa peneliti bahwa ada faktor lain yang berhubungan erat dengan kinerja bidan dalam pelaksanaan asuhan kebidanan persalinan selain persepsi tentang penghargaan yaitu seperti usia bidan, tingkat pendidikan, persepsi tehadap kepemimpinan, beban kerja serta motivasi kerja. Pendapat peneliti ini didasarkan pada teori yang dikemukakan oleh Happinasari (2017) kinerja merupakan keluaran hasil pada suatu fungsi jabatan atau seluruh aktivitas kerja dalam periode tertentu.

Menurut hasil wawancara tidak terstruktur yang dilakukan peneliti dengan beberapa responden, memaparkan bahwa insentif yang diterima bidan saat ini cukup memadai dan mengalami peningkatan dibanding tahun sebelumnya. Hal ini dipertegas oleh kepala Puskesmas Meranti memaparkan bahwa dengan adanya BPJS dan dana atau bantuan operasional kesehatan (BOK), dapat menambah tunjangan bidan.

Tabel 4. Hubungan Pengalaman Dengan Kinerja Bidan Dalam APN Di Kabupaten Merangin Tahun 2019

\begin{tabular}{lcccccccc}
\hline \multicolumn{1}{c}{ Pengalaman } & \multicolumn{3}{c}{ Kinerja Bidan } & \multicolumn{3}{c}{ Total } & p value & OR (95\% Cl) \\
& & $\mathrm{f}$ & $\%$ & $\mathrm{~F}$ & $\%$ & $\mathrm{f}$ & $\%$ & \\
\hline Kurang & 25 & 75,8 & 8 & 24,2 & 33 & 100 & 0,000 & $0,7292(2,683-9,818)$ \\
Baik & 15 & 30 & 35 & 70 & 50 & 100 & & \\
Total & 40 & 48,2 & 43 & 51,8 & 83 & 100 & & \\
\hline
\end{tabular}

Hasil penelitian menunjukkan bahwa kinerja bidan yang baik lebih banyak pada bidan yang memiliki pengalaman baik (70\%). Hasil uji statistik menunjukkan ada hubungan pengalaman bidan dengan kinerja bidan dalam pelaksanaan APN $(p=0,000)$ dengan OR $(7,292$ ; 95\% Cl=2,683-19,818).

Penelitian ini bertolak belakang yang dilakukan Fajriani (2000) yang menyatakan tidak ada hubungan pengalaman dengan kinerja bidan dengan $p$ value $=$ 0.678 .

Hasil analisis distribusi frekuensi diketahui bahwa kinerja responden yang baik cenderung lebih tinggi pada responden dengan pengalaman baik dibandingkan dengan responden dengan pengalaman kurang. Hal tersebut karena Menurut Siagian (2011) menyatakan bahwa pengalaman seseorang dalam melakukan pekerjaan tertentu secara terus menerus dalam waktu yang cukup lama akan dapat meningkatkan kedewasaan teknisnya. Pengalaman akan menjadikan kinerja seorang Bidan lebih baik lagi kedepannya. Menurut pengakuan beberapa Bidan, mereka memiliki intuisi atau bisa memprediksi setiap komplikasi persalinan secara dini, mampu melakukan penatalaksanaan komplikasi persalinan jika ia telah berlatih dengan sering untuk melakukan asuhan persalinan.

Dalam tulisan yang lain Siagian menyatakan bahwa pengalaman adalah keseluruhan pelajaran yang dipetik seseorang dari peristiwa-peristiwa yang dilalui dalam perjalanan hidupnya (Siagian, 2012). Proses pembelajaran juga melibatkan pengalaman, artinya pengalaman hidup penting untuk pembelajaran yang dapat diperoleh secara langsung melalui observasi atau praktek lapangan, atau dapat pula diperoleh secara tidak langsung misalnya melalui membaca, jika pengalaman menghasilkan perubahan perilaku yang relatif permanen kita dapat menyatakan bahwa proses pembelajaran betul-betul telah terjadi (Muchlas, 2008). 
Tabel 5. Hubungan Persepsi Tentang Peralatan APN Dengan Kinerja Bidan Dalam APN Di Kabupaten Merangin Tahun 2019

\begin{tabular}{cccccccccc}
\hline Persepsi tentang peralatan & \multicolumn{3}{c}{ Kinerja Bidan } & \multicolumn{3}{c}{ Total } & & p value & OR (95\% Cl) \\
& \multicolumn{2}{c}{ Tidak baik } & \multicolumn{2}{c}{ Baik } & & & & \\
& $\mathrm{f}$ & $\%$ & $\mathrm{f}$ & $\%$ & $\mathrm{f}$ & $\%$ & & \\
\hline Kurang & 12 & 40 & 18 & 60 & 30 & 100 & 0,261 & $0,595(0,240-1,476)$ \\
Baik & 28 & 52,8 & 25 & 47,2 & 53 & 100 & & \\
Total & 40 & 48,2 & 43 & 51,8 & 83 & 100 & & \\
\hline
\end{tabular}

Hasil penelitian diketahui bahwa kinerja bidan yang baik lebih banyak pada bidan yang memiliki persepsi tentang peralatan. Hasil uji statistik menunjukkan tidak ada hubungan persepsi tentang peralatan dengan kinerja bidan dalam pelaksanaan APN.

Penelitian ini tidak sejalan dengan penelitian Setiawan (2007) di Tasik Malaya yang menemukan hasil uji rank-spearman dengan perolehan $p$ value sebesar $0,000(p<0,05)$, terdapat hubungan bermakna antara ketersediaan sumberdaya/peralatan dengan kinerja bidan desa dalam pertolongan persalinan, meskipun kekuatan hubungan antara kedua variabel tersebut bersifat lemah ( $r$ o $=0,380$ ).

Menurut Hamzah (2008), sumberdaya secara langsung akan mempengaruhi motivasi bekerja bidan. Salah satu faktor yang menentukan kinerja seseorang adalah motivasi. Besar atau kecilnya pengaruh motivasi pada kinerja seseorang tergantung pada seberapa banyak intensitas motivasi yang diberikan. Motivasi juga merupakan dorongan dari dalam diri dan luar diri seseorang untuk melakukan sesuatu yang terlihat dari dimensi internal yang mendasari perilaku dan eksternal yang merupakan kelengkapan sarana dan prasarana penunjang kinerja.

Berdasarkan hasil wawancara yang dilakukan pada beberapa responden ditemukan bahwa sarana prasarana yang tersedia di Puskesmas pada umumnya sudah tersedia dengan baik. Namun berbeda hal nya dengan prasarana di Puskesmas pembantu maupun Puskesmas kelurahan, beberapa diantaranya masih ada yang tidak dialiri air. Selain itu ruangan KIA di beberapa
Puskesmas belum ada perbaikan, ruangan masih terlihat gelap dan kurang pencahayaan. Adapun kendala terebut sudah dilakukan penatalaksanaan oleh kepala puskesmas berupa kenaikan usulan dan anggaran kepada pemerintah dan dinas kesehatan untuk perbaikan kondisi ruangan.

Pendapat peneliti ini didasarkan pada teori yang dikemukakan oleh Happinasari (2017) kinerja merupakan keluaran hasil pada suatu fungsi jabatan atau seluruh aktivitas kerja dalam periode tertentu. Kinerja juga merupakan kombinasi antara kemampuan dan usaha untuk menghasilkan apa yang dikerjakan. Agar dapat menghasilkan kinerja yang baik seseorang memiliki kemampuan, kemauan serta usaha dan dukungan dari lingkungan. Kemampuan dan usaha akan menghasilkan motivasi kemudian setelah ada motivasi seseorang akan menampilkan perilaku untuk bekerja.

Kaitannya adalah jika ingin menghasilkan kinerja yang baik dari seorang bidan, ia terlebih dahulu harus mempunyai motivasi yang baik juga. Motivasi yang baik bisa dibangun dari beberapa aspek seperti dukungan dari kondisi fisik bidan, lingkungan, sarana-prasarana, insentif yang didapatkan dan variabel-variabel lainnya. Jadi semua aspek variabel memiliki keterkaitan dan hubungan satu sama lain (Happinasari, 2017).

Permasalahan terkait motivasi bekerja bidan juga terlihat dari suasana bekerja yang kurang nyaman, kondisi ruangan yang sangat terbatas, sarana dan prasarana yang belum memadai dan sirkulasi udara yang kurang baik. Suasana kerja yang baik akan menimbulkan perasaan betah dan nyaman sehingga akan meningkatkan semangat kerja.

Tabel 6. Hubungan Keikutsertaan dalam Pelatihan Dengan Kinerja Bidan Dalam APN Di Kabupaten Merangin Tahun 2019

\begin{tabular}{|c|c|c|c|c|c|c|c|c|}
\hline \multirow{3}{*}{ Pelatihan } & \multicolumn{4}{|c|}{ Kinerja Bidan } & \multicolumn{2}{|c|}{ Total } & \multirow{3}{*}{$p$ value } & \multirow{3}{*}{ OR $(95 \% \mathrm{Cl})$} \\
\hline & \multicolumn{2}{|c|}{ Tidak baik } & \multicolumn{2}{|c|}{ Baik } & & & & \\
\hline & $f$ & $\%$ & $\mathrm{f}$ & $\%$ & f & $\%$ & & \\
\hline Tidak Mengikuti & 8 & 53,3 & & 46,7 & 15 & 100 & 0,660 & $0,778(0,254-0,385)$ \\
\hline Mengikuti & 32 & 47,1 & 36 & 52,9 & 68 & 100 & & \\
\hline Total & 40 & 48,2 & 43 & 51,8 & 83 & 100 & & \\
\hline
\end{tabular}

Hasil penelitian menunjukkan bahwa kinerja bidan yang baik lebih banyak pada bidan yang mengikuti pelatihan. Hasil uji statistik menunjukkan tidak ada hubungan pelatihan bidan dengan kinerja bidan dalam pelaksanaan APN.

Penelitian ini sejalan dengan hasil penelitian Panjaitan (2018), menyatakan bahwa tidak ada hubungan yang bermakna antara pelatihan dengan kinerja bidan dalam pelaksanaan keluarga berencana, dimana nilai $p: 1,000$.

Berdasarkan hasil keterangan oleh beberapa bidan koordinator puskesmas melalui wawancara tidak terstruktur diperoleh informasi bahwa pelatihan terkait APN, HBB maupun resusitasi hanya difokuskan pada bidang pemegang program saja dan tidak diratakan untuk seluruh bidan karena terkendala jumlah anggaran yang disediakan oleh dinas kesehatan kota maupun provinsi. Selain itu, pelatihan terkait pelaksanaan APN ini tidak pernah diadakan pelatihan khusus di Wilayah Kabupaten Merangin sehingga beberapa bidan yang belum mengikuti pelatihan tersebut masih dalam tahap menunggu giliran karena salah satu kebijakan di Dinas Kesehatan Kabupaten Merangin adalah mewajibkan kepada setiap bidan memiliki sala satu sertifikat pelatihan dari APN, HBB ataupun resusitasi sebagai persyaratan pengurusan izin praktik.

Berdasarkan hasil penelitian juga didapatkan bahwa sebagian besar responden yang belum mendapatkan pelatihan tetap memberikan kinerja yang baik. Hal ini dikarenakan bidan merasa mempunyai 
tanggung jawab dalam menjalankan setiap program untuk mencapai target atau cakupan, meski belum pernah mengikuti pelatihan namun dalam menjalankan tugas hanya berdasarkan pengalaman dan kebiasaan yang sering dilakukan tanpa memahami secara konsep bagaimana APN terstandar yang sesungguhnya.

Pentingnya bidan mengikuti pelatihan APN karena pelatihan APN merupakan upaya yang dilakukan untuk meningkatkan mutu pelayanan kesehatan melalui peningkatan keterampilan bidan dengan penetapan standar pelayanan APN dan pelatihan untuk penerapannya. Pada pelatihan APN, peserta latih harus menguasai pengetahuan dan keterampilan yang telah distandarkan sehingga mampu memberikan asuhan persalinan yang aman dan bersih serta mencegah terjadinya komplikasi pada ibu dan bayi baru lahir, baik disetiap tahapan persalinan, kelahiran bayi maupun pada masa nifas.

Tabel 7. Analisis Regresi Logistik Sederhana (Seleksi Bivariat)

\begin{tabular}{|c|c|c|c|}
\hline No & Variabel & $p$-value & Masuk Model \\
\hline 1 & Pengetahuan & 0,000 & + \\
\hline 2 & Sikap & 0,351 & - \\
\hline 3 & Pengalaman & 0,000 & + \\
\hline 4 & Persepsi tentang penghargaan & 0,991 & - \\
\hline 5 & Persepsi tentang peralatan APN & 0,261 & - \\
\hline 6 & Pelatihan (APN/HBB/Resusitasi) & 0,660 & - \\
\hline
\end{tabular}

Hasil analisis bivariat menyimpulkan bahwa variable yang mempunyai nilai $p<0,25$ yaitu pengetahuan dan pengalaman. Maka kedua variable tersebut dimasukan kedalam analisis multivariate.

Analisis Regresi Logistik Berganda

Tabel 8. Analisis Faktor Paling Dominan Yang Berhubungan Dengan Kinerja Bidan Dalam Pelaksanaan APN Di Wilayah Kerja Dinas Kesehatan Kabupaten Merangin Tahun 2018

\begin{tabular}{lrrrrrr}
\hline \multicolumn{1}{c}{ Variabel } & B & \multicolumn{1}{c}{ SE } & Wald & df & \multicolumn{1}{c}{ Sig. } & Exp(B) \\
\hline Tingkat pengetahuan & 3.203 & .796 & 16.197 & 1 & .000 & 24.607 \\
Pengalaman & 2.883 & .802 & 12.928 & 1 & .000 & 17.871 \\
Constant & -9.112 & 2.204 & 17.093 & 1 & .000 & .000 \\
\hline
\end{tabular}

Hasil analisa multivariat penelitian mengenai faktor determinan kinerja bidan dalam pelaksanaan APN di Kabupaten Merangin tahun 2019 dengan uji regresi linear berganda diperoleh 1 variabel yang paling berpengaruh terhadap variabel independen yaitu varibel tingkat pengetahuan dengan nilai exponent betha (expB) yaitu 24,607 artinya jika tingkat pengetahuan bidan tentang APN semakin tinggi maka kinerja bidan dalam pelaksanaan APN berpeluang 24 kali lebih baik.

Menurut Ilyas (2001) kinerja didefinisikan sebagai ungkapan kemampuan yang didasari oleh pengetahuan, sikap, keterampilan dan motivasi dalam menghasilkan sesuatu. Pendapat Timpe (1999) tentang faktor-faktor yang mempengaruhi kinerja terdiri dari faktor internal dan faktor eksternal. Faktor Internal (disposisional) yaitu faktor yang dihubungkan dengan sifat-sifat seseorang, misalnya kinerja seseorang baik disebabkan karena mempunyai kemampuan tinggi dan seseorang itu tipe pekerja keras, sedangkan seseorang mempunyai kinerja jelek disebabkan orang tersebut mempunyai kemampuan rendah dan orang tersebut tidak memiliki upaya-upaya untuk memperbaiki kemampuannya. Faktor Eskternal yaitu faktor-faktor yang mempengaruhi kinerja seseorang yang berasal dari lingkungan, seperti perilaku, sikap dan tindakan-tindakan rekan kerja, bawahan atau pimpinan, fasilitas kerja dan iklim organisasi (llyas, 2001).

\section{SIMPULAN}

Separuh bidan memiliki kinerja yang baik dalam APN, lebih dari separuh bidan memiliki tingkat pengetahuan yang rendah tentang APN, lebih dari separuh bidan memiliki sikap yang positif tentang APN, memiliki persepsi terhadap penghargaan yang baik dan lebih dari separuh bidan memiliki pengalaman yang baik dalam APN serta juga memiliki persepsi yang baik tentang peralatan yang digunakan dan sebagian besar bidan telah mengikuti salah satu jenis pelatihan (APN/HBB dan Resusitasi).

Ada hubungan tingkat pengetahuan dan pengalaman dengan kinerja bidan dalam pelaksanaan APN di Kabupaten Merangin.Ada hubungan, tidak ada hubungan sikap, persepsi terhadap penghargaan,pengalaman, persepsi tentang peralatan dan pelatihan dengan kinerja bidan dalam pelaksanaan APN di Kabupaten Merangin.

Pengetahuan bidan merupakan faktor yang paling dominan berhubungan dengan kinerja bidan dalam pelaksanaan APN di Kabupaten Merangin.

\section{DAFTAR PUSTAKA}

Aswad, H.N. (2016). Pengaruh Tingkat Pendidikan, Pelatihan dan Kompensasi Terhadap Kinerja Perawat di Rumah Sakit UIT Makassar. Jurnal Mirai Management,

Azwar, S. (2011). Reliabilitas dan Validitas. Yogyakarta : Pustaka Pelajar.

Cunningham, GF., Leveno, KJ., Bloom, SL., Hauth, JC., Rouse, DJ., Spong, CY .(2013). Wiliams Obstetric. (Edisi 23 Vol 1). Alih bahasa: Brahm U. Pendit. Jakarta : EGC.

Debbie Holmes, P N. (2011). Buku Ajar IImu Kebidanan. Jakarta: EGC.

Dinas Kesehatan Provinsi Jambi. (2016). Profil Dinas Kesehatan Provinsi Jambi 2015. Padang: Dinas Kesehatan Provinsi Jambi.

Djunawan, A. (2015). Analisis Hubungan Kerjasama, Motivasi, Dan Sikap Bidan Dengan Kinerja Dalam Pelayanan Antenatal Pada Era JKN Di 
Kecamatan Kejayan Kabupaten Pasuruan. Jurnal administrasi kesehatan. Vol 3 (1).pp.11-20.

Hamzah, B. U. (2008). Teoti Motivasi dan Pengukurannya. Bumi Aksara: Jakarta.

Happinasari, OD., Patria S.J.,Kartini, A.(2017). Hubungan Persepsi Kompensasi Terhadap Kinerja Bidan Desa dalam Pelaksanaan Program Kelas Ibu Hamil di Puskesmas Kabupaten Purbalingga. Jurnal Imiah Kebidanan. Jurnal IImiah kebidanan . 8(1).pp. 95-102.

llyas., Y. (2001). Kinerja Teori, Penilaian dan Penelitian. Jakarta : Pusat Kajian Ekonomi Kesehatan FKM UI.

Longgupa, L.W. (2011). Pengaruh Faktor Pengetahuan, Sikap dan Pelatihan Asuhan Persalinan Normal Pada Kinerja Bidan Dalam Pertolongan Persalinan Normal Suatu Studi Eksploratif di Kota Palu Provinsi Sulawesi Tengah. JIK. Vol. I( 16). pp. 781-785.

Notoatmodjo, S. (2007). IImu Kesehatan Masyarakat : Prinsip-prinsip Dasar. Jakarta : PT. Rineka Cipta.

Panjaitan, N. (2018). Faktor-Faktor yang Mempengaruhi Rendahnya Kinerja Bidan dalam Pelaksanaan Program Keluarga Berencana di Puskesmas Aek Kanopan Kabupaten Labuhan Batu Utara. Diambil kembali dari Skripsi.

Setiawan, W.(2007). Beberapa Faktor Yang Berhubungan Dengan Kinerja Bidan Di Desa Dalam Pertolongan Persalinan Di Kabupaten Tasikmalaya. Masters Thesis, Program Pasca Sarjana Universitas Diponegoro. Semarang : Undip.

Siagian, S. (2012). Teori motivasi dan aplikasinya . Jakarta : Rineka cipta.

Sutrisno, Y.N., Suryoputro, A., Fatmasari, E.Y. (2017). Faktor-Faktor yang Berhubungan dengan Kinerja Perawat Rawat Inap di RSUD Kota Semarang. Jurnal Kesehatan Masyarakat . Vol 5(1).pp.142149.

Timpe AD. (1999).Seri ilmu dan manajemen bisnis "Kinerja". Jakarta : Gramedia Asri media.

Wattimena,M. (2008). Analisis Penerapan Standar Asuhan Persalinan Normal (APN) Oleh Bidan Di Rumah Sakit Umum Daerah Kabupaten Sorong Papua Barat Tahun 2008. Thesis. Program Studi Pasca Sarjana Universitas Diponegoro Semarang. Semarang.

Zulfina, R., Faisal. (2012) . Faktor-Faktor Yang Berhubungan Dengan Kinerja Petugas Pelaksana Farmasi Di Puskesmas Induk Kabupaten Aceh Selatan. Jurnal UII.pp.1-9 